\title{
COMO SE PENSA?
}

Coordenador: Octavio Ianni (Professor emérito da USP)

Expositores: $\quad$ Renato Lessa (Iuperj)

Marco Aurélio Nogueira (UNESP/Araraquara)

Luiz Eduardo Soares (Assessor da Prefeitura

Municipal de Porto Alegre) 



\section{DA ARTE DE FAZER AS BOAS PERGUNTAS}

RENATO LESSA

Em primeiro lugar, talvez o momento mais sincero da minha fala: os agradecimentos muito fortes à Amélia, por esse convite irrecusável de estar aqui nessa cerimônia, nessa comemoração dos 25 anos do CEDEC. As razões para atender o convite têm a ver com esse caráter irrecusável, que diz da importância do CEDEC, do trabalho por ele desenvolvido e com o carinho e admiração intelectual que tenho com as pessoas que fizeram e fazem o CEDEC. Mas, além disso, eu devo confessar que uma marca extremamente pessoal, uma espécie de datação pessoal, também pesa na aceitação do convite: o CEDEC faz 25 anos e há 25 anos atrás, no seu seminário de inauguração, na Rua Monte Alegre, eu estive presente, apresentando meu primeiro trabalho como pesquisador autônomo, aos 21 anos de idade. Posso dizer que comecei a minha trajetória no seminário do CEDEC. Lembrar disso aqui, hoje, é motivo de muita alegria. Posso dizer, eu tenho uma razão a mais do que os meus colegas para estar aqui.

Outro aspecto importante é o fato de esse seminário se realizar aqui, na Maria Antônia, marca importante da minha geração, um ícone da sua entrada na política. As fotos na parede - dos conflitos com a "turma" do Mackenzie - têm vida, evocam a linguagem da política no momento em que nela entramos e provocam sensações estranhas. Algo assemelhado à sensação que Woody Allen diz ter quando escuta a "Cavalgada das Valquírias", de Wagner. Ele diz mas ou menos o seguinte: "toda vez que eu escuto Wagner eu tenho vontade de invadir a Polônia”. É como se eu estando aqui, eu tivesse vontade de atravessar a rua e atirar pedras, continuando os gestos eternizados pelas fotografias. Mas asseguro-lhes que não o farei. Trata-se apenas de uma sensação que eu acho que devo compartilhar com os colegas e que de algum modo está inscrita em minha biografia. Então, isso tudo faz desse convite uma oportunidade e um chamamento irrecusável. 
O desenho do presente seminário encerra uma dura divisão do trabalho. Ontem, Gildo Marçal Brandão, Luiz Werneck Vianna e Boaventura de Sousa Santos encarregaram-se do que poderíamos designar como a dimensão deontológica da nossa conversa, envolvida na pergunta "por que pensar?". Como resultado, testemunhamos uma pungente exortação do dever do pensamento, em uma oportunidade para que proposições de caráter ético, que dizem respeito ao imperativo do pensamento, se manifestassem. Hoje à tarde, na sequiência, outros colegas (Carlos Nelson Coutinho, Fábio Konder Comparato e Francisco de Oliveira) vão ocupar-se de como pensar. Trata-se, na verdade, de uma dimensão poiética, de natureza inventiva e propositiva. Poder indicar o que merece ser pensado, o que é intelectualmente digno, configura um âmbito de liberdade muito invejável.

\section{QUESTIONAR COMO SE PENSA}

Agora, trata-se de enfrentar a dura questão "como se pensa?". Esta é a parte dessa divisão do trabalho que caiu sobre os meus colegas de mesa, Luiz Eduardo Soares e Marco Aurélio Nogueira. Que alternativas seguir para tratar, para levar a sério a solicitação que o CEDEC nos fez? Uma descrição técnica, distante, a respeito do que tem sido feito nas nossas disciplinas? Não sei se seria capaz de fazer, e não sei se gostaria de fazer. Temo que, por razões de autenticidade, vou interpretar o convite para tratar de como se pensa como uma oportunidade para falar um pouco de um certo litígio, de um certo dissídio meu com relação ao que a minha disciplina tem feito quando pensa seus objetos.

Para isso, eu gostaria de partir da seguinte premissa: todo problema intelectual tem a forma de uma pergunta. Como nós não acreditamos mais na velha fábula do empirismo de que os fatos falam por si mesmos, somos obrigados a reconhecer que a atividade cognitiva exige a presença de problemas intelectuais, de perguntas dirigidas a nossos experimentos. Sendo assim, é fundamental saber de onde partem essas perguntas, como elas são possíveis, como elas são estabelecidas, já que as perguntas não são propriedades naturais do mundo, o mundo ele mesmo não nos diz nada e não é constitutivamente habitado por interrogações. Ele é mobilizado cognitivamente na medida em que o descrevemos e o circunscrevemos no idioma de nossas tradições intelectuais e disciplinares.

Parte importante da Ciência Política contemporânea caracterizase pelo afastamento com relação a esta dimensão. Ao supor, tacitamente, 
que opera com uma linguagem natural, que designa de forma não problemática os seus objetos, ela desconsidera que a possibilidade de falar do mundo depende da presença de tradições intelectuais fortes, que constituíram tanto os objetos como os idiomas de seus modos de tratamento. A chamada revolução behaviorista que ocorreu na década de 50 na Ciência Política americana produziu consequiências muito fortes na direção desse esquecimento. A idéia de que temos uma ciência que pode, como Spinosa, falar dos homens sem rir nem chorar, que pode mensurar fatos e que pode tratar de objetos para cuja descrição a subjetividade e a normatividade não aparecem como elementos constituintes, dispensa considerações de corte filosófico. Tudo isso podendo ser demonstrado numa linguagem que cada vez mais se distancia da linguagem comum, da linguagem ordinária; uma linguagem que quanto mais extraordinária se faz, magicamente maior é o seu grau de cientificidade. Note-se, desde já, a tensão: ao mesmo tempo em que supõe-se a possibilidade de um saber das coisas tal como elas são, a linguagem que deriva desse feliz encontro entre mundo e pensamento nada tem de ordinária; ela recusa a língua da vida comum e busca simetria, parcimônia simbólica e precisão.

Por que a disciplina se constitui dessa maneira, com essa pretensão de positividade? O que está em jogo nisso? As respostas a isso são complexas e necessariamente controversas. Mas é possível afirmar que nem sempre foi assim e que, fazendo um nexo com alguns problemas que aqui foram discutidos ontem, é possível pensar a tradição da teoria política como uma espécie de tradição perdida. Uma tradição que não sei se será retomada nos seus termos originais, mas sobre a qual, de qualquer maneira e por contraste, é relevante falar. Nem que seja um pouco como em Rousseau, que, quando falava no estado de natureza, dizia que ele talvez nunca tenha existido e que provavelmente nunca venha a existir, mas que ainda assim é importante considerá-lo: na verdade falar dele é condição para que se entenda a sua negação, vigente no mundo histórico e factual.

\section{A BOA CÓPIA DO INEXISTENTE}

A tradição da teoria política, quando lidava com o mundo, quando considerava a positividade do mundo, era marcada pela atenção ao que ontem aqui Boaventura de Sousa Santos designou como a negatividade desse próprio mundo. Em outros termos, tratava-se de falar das coisas que existem e que são atestadas por todos, mas tratava-se de dizer também do 
que não há, ou do que se julga estar a faltar. Radicalizando um pouco o ponto, é possível dizer que a tradição da teoria política é a de lidar com objetos que não existem, de tratar com o que não há, ainda. Há várias discussões e notações que podem indicar esse tipo de abordagem: as noções da lógica modal, a concepção de Wittgenstein a respeito dos jogos de linguagem, a idéia de Nelson Goodman de construções de mundos etc. Mas reporto-me aqui a uma referência de minha predileção e que revisita uma discussão ocorrida no contexto do Renascimento tardio italiano no campo da estética. Nela, um esteta italiano de nome Gregorio Comaninni propõe uma interpretação dura de Platão a respeito do tema da mímesis. Comaninni chama nossa atenção para a existência, na letra platônica, de duas formas possíveis de imitação diante do mundo, duas formas de conhecimento e de exercício mimético. A primeira delas seria a boa mímese - a imitação eicástica, ou assemelhadora -, que seria uma cópia do mundo, uma reprodução deste no plano da linguagem e do registro estético. A outra seria a má cópia - a imitação fantástica - que segundo o nosso esteta copia ou imita coisas não existentes. Lembro-me do impacto que tive quando li isso pela primeira vez, em um antigo e belo livro de Pierre Maxime-Schul (Platon et l'art de son temps); de como fiquei inteiramente estarrecido e cativado por essa idéia de copiar alguma coisa que não existe. Como é possível uma coisa dessa?

Olhando para a minha disciplina, tentando ver algo além desse presente curto que ela oferece como instrumento de análise, dessa reedição um tanto lebiniziana de um mundo completo e dotado de total plenitude, dei-me conta de que a tradição esquecida da teoria política é constituída por uma linhagem confusa e babélica de autores, de pensadores, que inventaram uma série de rotas cognitivas em direção ao mundo - ou melhor, em direção a seus mundos -, em grande medida orientados por essa perspectiva de copiar alguma coisa que não existe, ou de acrescentar ao existente algo que este não contém. Ainda que orientados por algum imperativo político ou ético de curto prazo, de falar das coisas que estavam a desenrolar-se de modo imediato, de responder a questões emergenciais, os clássicos da teoria política fizeram mais do que isso, na medida em que indicaram objetos não existentes. Alguns desses objetos seguem - para o bem ou para o mal - não existindo. Quanto a outros, é possível percebê-los no mundo, andando entre nós, como formas decantadas, como invenções materializadas, como valores que se integraram à nossa tradição civilizatória, como fundamentos normativos de uma série de instituições, como códigos sem os quais nossas vidas seriam quiméricas e desprovidas de sen- 
tido. As representações que fazemos da dura materialidade de nossas formas civilizatórias resultam de invenções, de esforços utópicos de visionários, mais ou menos ligados ao que se passava no mundo ao seu redor, que procuraram desenvolver uma forma de reflexão não cativa à positividade do mundo, à rodrigueana idiotia da objetividade.

A assim chamada "revolução behaviorista" dos anos 50 indicou a necessidade de uma rendição da ciência diante da vida tal como ela se apresenta. Trata-se, antes de mais nada, de dizer o que há, e de fazê-lo em um vocabulário distinto dos usos e costumes vocabulares da vida ordinária. Vemo-nos diante de uma curiosa petição realista: o reconhecimento fático do que há - e nada mais do que isso - e a exigência de uma linguagem nãoordinária. É a linguagem matematizada e formalizada, sonhada por Pitágoras e defendida por Platão, que triunfa sobre as prédicas dos sofistas Górgias e Protágoras, seres da vida comum e dos jogos de persuasão. É a busca hobbesiana por axiomas, capazes de proporcionar corolários invencíveis, que derrota a esperança humeana de um saber imperfeito da política sustentado na experiência, nas crenças e na linguagem da common life.

Mas, antes que essas pretensões positivas da Ciência Política normal dos anos cinqüenta tivessem vindo à tona, é possível localizar as marcações mais gerais dessa virada positiva e realista já no início do século XX, como produto de uma convergência não coordenada de uma série de autores cujas obras interpelaram duramente as heranças utópicas que o século de Brahms legou para o século de Schoenberg.

$\mathrm{O}$ realismo das décadas iniciais do século interditava tanto as possibilidades de uma sociedade solidária, sustentada pela vasta tradição socialista, como as de uma sociabilidade e de uma ordem institucional democráticas, fundadas na tradição liberal-democrática do século XIX. Uma sociabilidade fundada em uma noção de indivíduo racional, não no sentido contemporâneo, e razoável: bem informado, capaz de discernir o que se passa no mundo público, orientado para a vida pública, e que complementa a sua fruição individual enquanto indivíduo, como um agente que usufrui de uma liberdade negativa, com a inserção no mundo público e com o exercício de uma liberdade positiva

A promessa solidária e a promessa libertária, nesse sentido, foram duramente implodidas pela vida e por diversos autores, no início do século 20, que julgavam em suas obras apresentar a vida e a política tal como elas são: a política como relação marcada pela tensão amigo-inimigo e como lugar do sofrimento, do perigo e do combate; a imagem da sociedade como marcada indelevelmente pela divisão entre elites e massas, 
como lugar de uma diferença que não pode ser cancelada; sobretudo a idéia da experiência da sociedade como partição, como algo marcado pelo indelével mal-estar da inserção individual no mundo social. Enfim, esta atividade não coordenada de uma série de pensadores, ao mesmo tempo em que soterra esperanças utópicas de séculos precedentes, prepara como que um ambiente intelectual que vai ser fundamental para reconstrução da própria teoria democrática, a partir dos anos 40. Nesse ponto já estou a falar de Schumpeter e a indicar um pouco o que vai ser posto no mundo com a revolução behaviorista, que pretende destituir a reflexão política de qualquer compromisso e de qualquer inscrição mais normativa. A ciência política se transforma numa techné: uma observação metódica dos fatos, capaz de mostrar como a vida se dá, como o fatos que povoam e configuram o campo político se estruturam.

\section{A TIRANIA DO MÉTODO}

Posso estar exagerando um pouco na minha descrição, mas algumas implicações dessa orientação teórica e, digamos assim, ontológica, vão estar presentes entre nós num elogio bastante repetido e sempre reiterado da metodologia e da idéia de que pensar significa fazê-lo de uma maneira metodologicamente organizada. Há uma idéia interessante desenvolvida por Sheldon Wolin, por ele designada como metodismo. Methodism, se traduzido em português, denota outras religiões, para além da professada pelos objetivistas. Podemos optar por metodolatria. No sentido de Wolin, metodismo está associado à idéia de shaping of the mind. $\mathrm{Ou}$ seja, não se trata de mero recurso exterior ao pensamento, que ele usufrui ou utiliza para produzir achados, mas de alguma coisa que configura a própria capacidade de reflexão e a nossa possibilidade de dizer coisas a respeito do mundo; a idéia de que o meio, de que o instrumento, se transforma em premissa para o mundo. Mais do que recurso à disposição do pensamento, o método se faz, ele mesmo, o pensamento.

$\mathrm{O}$ próprio Sheldon Wolin, referindo-se à centralidade que o método vai assumir na disciplina - com o conseqüente rebaixamento da idéia de teoria, que para ele tem uma dimensão épica de invenção de coisas -, indica que isto segrega conseqüências pesadas no que diz respeito ao aspecto pedagógico, ou seja, de que disciplina estamos ensinando.

Como estamos ensinando a pensar? Como é que se pensa a partir desse registro disciplinar que é cativo de uma sequiência muito perver- 
sa? Até a minha geração, basicamente, nós fomos socializados na convivência com esses grandes autores, com essa tradição mais utópica, mais diversificada da teoria política. Isso está presente, de certa maneira, na prática profissional de alguns colegas. Na medida em que essa dimensão fenece, ou até mesmo desaparece, em nosso horizonte, a preocupação que fica é a seguinte: que objetos novos estão sendo postos à consideração de gerações futuras? Em outros termos, trata-se de dizer que de alguma maneira estão sendo limitadas as possibilidades de tratamento de novos objetos, a consideração de novos problemas.

Quando menciono essa redução da disciplina ao que há, não estou de maneira nenhuma querendo dizer que esses fenômenos que habitam o chamado mundo político, fenômenos aprisionados na dimensão institucional, não devam ser tratados. Evidente que devem, pela simples razão de que estão aí, têm centralidade, o seu desempenho produz conseqüências públicas evidentes, portanto há que se ocupar deles.

$\mathrm{O}$ ponto que eu procuro desenvolver quando menciono essa redução é a nossa incapacidade, a nossa cegueira disciplinar para tratar de outras coisas, de outras questões tão relevantes quanto aquelas. Para usar uma linguagem forte, é no mínimo intrigante, por exemplo, que as ciências sociais não tenham na sua pauta, na sua agenda de objetos, talvez o principal evento do século XX. Auschwitz não é um tema corrente de preocupação de cientistas sociais; a Ciência Social deteve-se no pórtico dos campos de concentração - eu estou usando Auschwitz como metáfora de alguma coisa que eu cinicamente poderia descrever como talvez a política pública mais bem-sucedida do século $\mathrm{XX}$, em termos dos seus efeitos. Poderíamos estender a menção para genocídios, para limpezas étnicas, para uma série de fenômenos que têm, evidentemente, implicações demográficas brutais, e que os nossos instrumentos disciplinares não são capazes de detectar, de lidar, porque estamos exclusivamente voltados para dimensões ligadas ao processo político, ao processo institucional.

Essa cegueira analítica nos interpela e diz muito a respeito do tipo de redução, do tipo de foco que a disciplina acabou por adotar diante da possibilidade incomensurável, variada, incontável de temas que poderiam ser por ela tratados. Isso, em grande medida, se deve ao fato de que pensar hoje se transformou num exercício disciplinar. Vivemos do pensamento, não vivemos para o pensamento, somos profissionais do pensamento. Sendo profissionais do pensamento, estamos em departamentos que dividem-se disciplinarmente, e sendo profissionais de departamentos acabamos naturalizando essas divisões e isso tem efeitos terríveis sobre a 
capacidade de.... Não. Eu não vou fazer aqui um discurso surrado pela interdisciplinaridade. A idéia não é essa. Mais grave do que não poder praticar exercícios interdisciplinares é termos perdido a perspectiva prédisciplinar. Isso é que me parece mais terrível. Boaventura ontem falava do novo cientista social e de uma nova ciência social. Eu cá comigo imagino uma ciência social nova, na medida em que ela seja capaz de simular uma situação, talvez, pré-disciplinar, onde essas compartimentalizações não se estruturaram. Isso teria implicações pedagógicas evidente, reconfiguração de cursos, reconfiguração de currículos, eu acho que não é o momento de falar disso, porque isso seria falar de como pensar, como se deve pensar, ou de pelo menos, conduzir a conversa nessa direção. Não seria genuíno da minha parte tentar tratar dessa questão sem mencionar, portanto, um certo desconforto que tem a ver com a supressão unilateral dos nossos vínculos com a filosofia, com a história, com a antropologia, com a literatura, com o domínio da arte, e essa miragem de construir um saber cuja cientificidade é a razão direta do seu isolamento analítico, da sua falta de memória.

\section{E O BRASIL NISSO?}

Penso que a Ciência Política que se tem feito no Brasil não esteve imune a esse movimento objetivista que eu estou mencionando, e que tem a ver com episódios intelectuais que aconteceram em outros lugares. No que diz respeito ao Brasil, o que eu acho mais interessante para a nossa consideração aqui tem a ver com algo que foi tocado na conversa de ontem, com a idéia de que perdemos uma certa capacidade de falar do Brasil como um domínio que possa ser interpretado ou inventado. Falo da idéia de interpretação do Brasil, da idéia de pensar o país, com toda megalomania inevitável que essa tentativa sempre segrega. Mas, com frequiência essa megalomania tem dimensões generosas - eu estou a referir-me aqui à nossa belíssima tradição de ensaísmo, aos ensaístas do século XIX, por exemplo. Tavares Bastos foi mencionado aqui ontem; Joaquim Nabuco, idem; estou a pensar também, no século XX, em Oliveira Vianna, em Azevedo Amaral, em Gilberto Freyre e, sobretudo, em uma tradição de reflexão que, inspirada em Oliveira Vianna, chama a atenção para o caráter fragmentado, para o caráter, digamos assim, invertebrado, da experiência social brasileira, como achado analítico e como aviso.

Werneck Vianna ontem mencionou o belíssimo e seminal trabalho de Maria Silvia de Carvalho Franco (Homens livres na ordem escrav- 
ocrata), que embora não faça referência a Oliveira Vianna, é dele um complemento forte. A leitura combinada é uma delícia: da leitura de Oliveira Vianna chegamos, pela descrição do insolidarismo, ao mundo que aparece em Maria Silvia de Carvalho Franco: o código disseminado de violência; a idéia de que cada ser humano é uma ilha e deve preservar a todo custo a sua honra pessoal.

Essa percepção está associada à visão de autores tais como o próprio Oliveira Vianna, que indica o caráter natural e fragmentado da experiência brasileira. Oliveira Vianna chega a falar, por exemplo, da dendrofilia do homo colonialis brasileiro, como aspecto fundamental das suas interações sociais, e daí faz derivar uma advertência: há que criar um mundo público, há que inventar uma dimensão na qual haja linguagem pública, ainda que essa dimensão, na terapia proposta por Oliveira Vianna, passe por um dirigismo estatal discutível. Mas, o problema do Oliveira Vianna não é tanto a terapia que ele propõe, mas sim o diagnóstico: a idéia de que se esse artifício de criação de um mundo público não for produzido, a exuberante natureza brasileira da dispersão, da ausência da palavra, da ausência de nexo societário farão o seu império, marcado por uma combinação entre privatismo e despotismo.

Estou aqui a falar de Oliveira Vianna não só porque gosto muito dele, o que é evidente, mas porque ele nos interpela fortemente, em nossos mais básicos costumes cognitivos. Não se trata, é evidente, de adotar suas prescrições, mas de reconhecer a falta que faz uma reflexão dessa natureza, voltada para perguntas do seguinte tipo: que mundo público é este que dispomos, que configuração pública imaginar como contraponto à fragmentação societária e ao fideísmo de mercado que se apresenta como sua cura natural e espontânea?

Penso que temos nessas remissões algo merece alguma reflexão nossa. Ao perdermos de vista a tradição ensaística, com toda a sua imprecisão, com todo o seu impressionismo, com toda a sua incapacidade de produzir evidências estatisticamente organizadas, nos transformamos em uma espécie de clones de Gulliver, em Liliput. Do pobre Lemuel, que, náufrago, dá a uma praia na qual desfalece semimorto e depois de criteriosa e longa consulta a cada um dos seus sentidos, descobre, num rigoroso processo indutivo, que milhares de pequenos anõezinhos o prenderam ao mundo. Gulliver aparece aqui como índice de um pensador totalmente submetido à pequena indução, à consulta aos pequenos objetos. $\mathrm{O}$ meu temor é que o aprisionamento acadêmico da reflexão política nos transforme em cativos desses pequenos objetos, que eventualmente podem dizer coisas 
interessantes sobre aspectos pontuais, aspectos fortes do mundo institucional. Mas quem cuidará do que não há? Acho que esse é o ponto fundamental: em um certo sentido estamos perdendo a capacidade de pensar o que não há e, mais grave do que isso, estamos perdendo a capacidade de ensinar aos nossos alunos que devemos pensar o que não há, ainda. 


\section{A SÍNTESE COMO PROBLEMA}

MARCO AURÉLIO NOGUEIRA

Inicialmente quero também agradecer muito ao convite da diretoria do CEDEC, na pessoa da Amélia, que teve a gentileza de me possibilitar participar de corpo e alma neste evento que, seguramente, é extraordinariamente importante. Aproveito e faço os meus cumprimentos pessoais ao CEDEC pelos 25 anos, e faço isso em nome do meu departamento e do diretor da minha faculdade, o colega José Antonio Segatto, que me pediu que fizesse essa referência aqui de viva voz e com toda a ênfase, já que o CEDEC é uma referência para a ciência social, e merece ser homenageado de uma maneira substantiva no dia de hoje.

Gostaria de fazer esse registro e aproveitar para fazer o primeiro gancho com a mesa de hoje. Acho que uma instituição que se propõe a comemorar seus 25 anos com uma pauta temática como essa seguramente é uma instituição que está vocacionada a agir com base, digamos assim, na independência e na ousadia, porque o convite que há nessas três mesas é para que a gente opere de modo independente e ousado, porque os temas relacionados ao pensar o Brasil, na maneira sobretudo como estão sugeridos aqui - o como pensar, por que pensar e como se pensa -, são convites para que a gente tente ousar em alguma direção.

Pensar o "como se pensa" no Brasil de hoje é pôr-se um tema radicalmente aberto. Ficamos, sem apelação, perante diversos problemas e nuances, passíveis de serem agregados e articulados de múltiplas maneiras. O presente texto tem objetivos modestos e pontuais: não pretende alcançar respostas, mas apenas fazer perguntas e sugerir uma agenda temática preliminar, selecionando, dentre os vários aspectos da questão, aqueles que, ao menos em princípio, parecem ser mais estratégicos ou fundamentais.

Interrogar-se a respeito do "como" é sempre enveredar por uma trilha onde aparecem o "quem", o "que" e o "onde": difícil pensar um ponto sem considerar os demais. Por isso, para refletir sobre o "como se pensa", 
parece-me necessário levar em conta (ao menos como pano de fundo) um leque de personagens e espaços institucionais. Antes de tudo, os intelectuais - estes decisivos protagonistas do mundo das idéias e dos conhecimentos -, mas também as pessoas em geral, o "senso comum", o saber espontâneo ou menos "educado". Também os políticos e os técnicos, certamente, e junto com eles, mas em registros mais específicos, os governantes e as oposições. A mídia e a universidade, inegavelmente dois dos principais centros de produção de conhecimentos, idéias, informações e pensamentos. Cada um destes sujeitos e espaços resolve à sua maneira o desafio do pensar, contribui de algum modo para a formação mesma dos parâmetros com que se pensa e sofre, em contrapartida, a influência e os condicionamentos do circuito cultural e institucional em que se pensa.

Teríamos de investigar, em segundo lugar, como estes personagens que pensam e fixam um modo específico de pensar se relacionam com aquilo que se poderia chamar de "pensamento dominante". E o que seria este "pensamento dominante"? Um sinônimo de "idéias das classes dominantes" ou o pensamento sintonizado com as correntes e os hábitos intelectuais mais fortes, ou seja, com o modo prevalecente de produzir idéias, com os valores e as ideologias predominantes, em suma, com o establishment intelectual? Para os efeitos da exposição que se seguirá, será a esta segunda acepção que estarei me referindo, ao falar em pensamento dominante.

É inevitável, ainda, que se associe o "como se pensa" ao "como se deve pensar", com o que se fica em meio a uma espécie de diálogo entre o que é e o que deveria ser. Deste ponto de vista, a pergunta sugere uma disputa em torno da verdade, uma avaliação a respeito da solidez teórica do modo dominante de pensar e do modo que deveria prevalecer, ou que talvez prevaleça nos espaços alternativos. Poderíamos discutir, assim, a questão de saber como se pensa o pensamento dominante, isto é, como se analisa criticamente o modo dominante de pensar e como se estrutura um modo alternativo de pensar, investigando-se a consistência teórica, as opções metodológicas, os temas e as ênfases de cada um destes modos de pensar - além, é claro, de se poder apreciar a real incidência prática de cada um deles.

Discutir o "como se pensa" não é, portanto, um exercício meramente teórico-metodológico, mas um exercício político-cultural, associado a correlações de forças, a projetos políticos, a quadros de valores e perspectivas, a lutas por hegemonias. Se quisermos discutir mesmo o problema, teremos de nos interrogar tanto a respeito do sistema de produção cultural mais abrangente - no caso, a indústria cultural -, quanto a respeito da maneira como os diversos sujeitos coletivos da sociedade (e, aqui, particu- 
larmente dos partidos e movimentos políticos) encaminham e viabilizam sua própria elaboração teórica. Teremos de olhar, portanto, não apenas para o circuito intelectual mais imediato, mas também para o mundo da cultura em sentido amplo, assim como para o Estado e a sociedade civil.

\section{DEMOCRATIZAÇÃO E MAL-ESTAR}

Isso posto, gostaria de fixar um ponto de referência preliminar, para nele ancorar a hipótese que pretendo apresentar aqui. Nos últimos quarenta ou cinqüenta anos, como evoluímos em termos de pensamento? As modificações foram tão expressivas que uma comparação entre o padrão prevalecente no início do século XXI e o que prevalecia na passagem da primeira para a segunda metade do século XX seria inconsistente e pouco razoável, tamanhas as diferenças de escala, de volume produzido, de gente envolvida, e sobretudo de estilo, de padrão, de temática. Em cinco ou seis décadas, a ciência se "democratizou" no Brasil. Não se disseminou de maneira equilibrada pelos diversos grupos sociais e regiões do país, muito ao contrário, mas certamente passou a envolver massas crescentes de pessoas, jovens sobretudo, acompanhando a marcha da expansão do ensino superior e a progressiva afirmação de uma cultura que valoriza a escolaridade e a formação continuada. Houve "democratização", também, no sentido de que se passou a produzir ciência em um número muito maior de centros e instituições, distribuídas nacionalmente. Com isso, a produção científica cresceu de modo impressionante, e continua a crescer de modo ainda mais impressionante a cada dia. Hoje, há muito mais informações soltas no ar e os conhecimentos são apropriados por muito mais gente. Dominamos mais dados, publicamos mais livros e artigos, organizamos mais encontros científicos, pesquisamos mais e mais sistematicamente, e nossa história, nosso passado e nossas especificidades como sociedade nacional estão muito mais transparentes. Graças ao ritmo inerente ao processo de racionalização e especialização a que nos associamos, dispomos hoje de uma vasta gama de investigações sobre os mais diferentes aspectos da nossa sociabilidade, da nossa política, da nossa economia e da nossa cultura. E isso para não falar dos avanços obtidos nos campos da física, da química, das ciências da vida, das matemáticas, que talvez sejam ainda mais expressivos e impressionantes.

Em suma, crescemos e avançamos categoricamente, seja em termos de produção de conhecimentos (pesquisa), seja em termos de repro- 
dução e distribuição (escolas). Tudo, além do mais, se acelerou. Fazemos coisas - e, portanto, produzimos idéias e conhecimentos - num ritmo muito mais rápido e ininterrupto. Não há mais intervalos de tempo entre uma "onda" e outra, que se sucedem quase freneticamente uma após outra, a ponto de se confundirem entre si e de nos confundirem. Em decorrência, as idéias circulam com muito maior rapidez, muitas vezes nos bloqueando a possibilidade mesma de frui-las: as idéias passam por nós, num fluxo complexo e acelerado, diante do qual ou refluímos - aferrando-nos à repetição do já conhecido -, ou adotamos posturas mais ou menos predatórias: pegamos o que nos interessa. Inevitável que o conhecimento avance, se acumule e se reproduza a partir de uma miríade de focos.

Tudo mudou tanto e tão rapidamente que ficamos sugestionados a achar que houve um corte - uma ruptura - entre o modo como pensávamos antes e o modo como pensamos agora. Nesta visão, não existiria uma mesma linha de pensamento evoluindo dialeticamente, mas dois pensamentos se hostilizando e se excluindo: o pensamento dos nossos maiores com suas ramificações institucionalizadas e suas grandes narrativas - e o pensamento atual, "americanizado" ao extremo e avesso às melhores tradições. Creio que este modo de pensar não se sustenta, e sugiro que talvez estejamos no mesmo fluxo de produção e distribuição de conhecimentos, só que em uma etapa diversa, mais avançada e por isso mesmo aparentemente negadora da anterior. $\mathrm{Na}$ verdade, há mais superação que negação (ou há negação no sentido preciso de superação: incorporação e elevação daquilo que é negado). Avançamos, mas não sem perder algo, não sem deixar pelo caminho algumas boas e importantes coisas.

Acontece, porém, que apesar de tanto avanço e progresso intelectual, há um flagrante mal-estar nos circuitos da produção e difusão de idéias e conhecimentos. Vivemos com a sensação de que falta algo, de que tanta informação e tanta gente envolvida na ativação do pensamento não estão sendo suficientes para gerar mais conhecimento efetivo, quer dizer, mais sabedoria e maior capacidade de compor visões de conjunto, articulações superiores e conexões ricas de sentido, a partir das quais se descortinem cenários reveladores de nossa experiência coletiva. Ficamos mais modernos em termos teórico-metodológicos, dominamos recursos intelectuais bem mais sofisticados, temos uma formidável rede de instituições produtoras de conhecimentos, a produção científica cresceu de modo impressionante, mas vemos o país real escapar a todo momento dos esquemas conceituais que mobilizamos para explicá-lo. Estamos mais fortes para abordar a realidade, mas acabamos prisioneiros de um modo de pen- 
sar que dá mais valor aos enquadramentos (à metodologia, seria possível dizer) e aos detalhes que às perspectivas abrangentes, históricas e totalizantes. Pensamos mais e de modo sempre mais tecnicamente correto, mas empurramos as utopias (os valores, as ideologias, os programas de ação) para fora do campo do pensar. Ficamos além, ou aquém, das paixões. Em suma, sabemos mais a respeito de mais coisas, mas temos enormes dificuldades para alcançar sínteses que expliquem de fato o Brasil e abram - justamente porque alcançam explicações efetivas - perspectivas mais consistentes de intervenção e construção do futuro.

Isto não significa, é evidente, que estejamos às cegas ou que não encontremos hoje, em nosso mundo cultural, inúmeros empreendimentos intelectuais bem sucedidos, frutificados na vasta rede institucional em que operam nossas ciências sociais. É preciso deixar bem claro, portanto, que não se está menosprezando, criticando ou "julgando" negativamente as ciências sociais brasileiras, que têm dado mostras seguidas de vitalidade, rigor e consistência teórica. Nosso sistema de produção, na área, cresceu quantitativa e qualitativamente ao longo das últimas décadas, e dele nascem, regularmente, contribuições fundamentais para o conhecimento do país. O ponto aqui é de outro teor, completamente afastado de qualquer intenção de fazer balanços ou avaliações pontuais.

Insinuar que o mal-estar dificulta o acesso a um melhor conhecimento não significa, também, que se possa deixar de reconhecer que somos caudatários de algumas consolidadas tradições teóricas e científicas, que, ainda quando nascidas e desenvolvidas em contextos bem diferentes (e bem distantes) dos atuais, continuam sendo básicas para o entendimento da realidade nacional, tanto que persistem como nossos interlocutores obrigatórios. Inserem-se aí, como é fácil perceber, todos os "maiores" do pensamento brasileiro, de Joaquim Nabuco, Oliveira Vianna e Sérgio Buarque de Holanda a Florestan Fernandes, Antonio Candido e Octavio Ianni, passando por Raymundo Faoro, Caio Prado Jr. e Nelson Werneck Sodré, para mencionar apenas alguns nomes de uma vasta galeria. Somente em parte estes são autores datados, até mesmo porque alguns deles continuam em plena atividade nos dias de hoje. Eles pertencem, porém, a uma outra geração intelectual, e apenas parcialmente refletem o estado atual do "como se pensa" hoje. Em alguma medida, são autores que foram relativamente "deslocados" pela atual onda intelectual em que nos encontramos, ainda que se mantenham como referências fundamentais. Passaram, curiosamente, a compor um expressivo agregado de intelectuais - mais jovens e mais velhos - que remam contra a corrente. Não estão isolados, muito menos "mortos". 


\section{O DIÁLOGO COM AS TRADIÇÕES E A RECONFIGURAÇÃO DOS INTELECTUAIS}

Não se consegue resolver a questão do "como se pensa" se não se considera o "como se pensou" o Brasil ao longo do tempo. O pensar de uma geração - o modo dominante de pensar numa dada fase - é sempre, necessariamente, um diálogo com tradições, perspectivas, métodos, conceitos, imagens, teses e hipóteses formuladas anteriormente. Também no plano do pensamento, cada geração explora a seu modo o legado recebido das gerações anteriores: "de um lado - já apontavam Marx e Engels na Ideologia Alemã - cada geração prossegue em condições completamente diferentes a atividade precedente, ao passo que, de outro lado, modifica as circunstâncias anteriores por meio de uma atividade totalmente diversa". O processo histórico (a mudança) ocorre muito lentamente: "as diferentes fases e os diversos interesses jamais são completamente ultrapassados, mas apenas subordinados ao interesse vitorioso, e vão-se arrastando durante séculos ao lado deste". O pensar, em suma, e junto com ele o "como se pensa", é sempre uma atualização do que e do como se pensou antes. Tratase, aqui, na verdade, de entender a natureza mesma do processo educacional, que, lembrava Gramsci, não pode evitar o diálogo com a cultura e as idéias existentes ou elaboradas em épocas pretéritas: "para instruir-se e educar-se é necessário um aparelho de cultura através do qual a geração velha transmite à geração nova toda a experiência do passado (de todas as velhas gerações passadas), faz com que adquira determinadas inclinações e hábitos (até físicos e técnicos, que se assimilam com a repetição) e transmite, enriquecido, o patrimônio do passado".

Deste ponto de vista, os anos 80 e 90 do século XX representaram um ponto avançado do relacionamento intelectual com as tradições teóricas e com as obras que "descobriram" e interpretaram o Brasil ao longo do século. Representaram a reiteração de um diálogo e foram ao mesmo tempo uma inflexão, uma ruptura com o passado. Sem querer imprimir maior rigor a esta discussão, nem ter a pretensão de abordar o tema de modo abrangente, creio que tal diálogo e tal ruptura se deram tendo como base as seguintes tradições: a) a narrativa histórico-sociológica de Oliveira Vianna, Sérgio Buarque de Holanda e Gilberto Freyre; b) a análise sociológica de Florestan Fernandes e da escola uspiana; c) a história político-econômica de Caio Prado Jr. e Celso Furtado; d) a elaboração teórica e a cultura política do Partido Comunista Brasileiro (PCB). 
Estas quatro tradições - distintas entre si, por vários motivos, tanto uma em relação a outra, como no que se refere aos autores que se inseriram em cada uma delas - tinham em comum alguns pontos importantes. Eram, antes de tudo, totalizantes, ainda que não necessariamente dialéticas. Buscavam a grande narrativa: a historicização, a visão abrangente e razoavelmente independente de comprovações empíricas, o contato estreito com a literatura, a filosofia, a arte. Todas queriam, também, fazer ciência e alcançar padrões superiores de rigor teórico. Tinham um projeto (nacional, mas não apenas) como perspectiva e guia de atuação: desejavam reconstruir a história para construir a nação, o Estado, a sociedade. E estavam imbuídas de uma vocação pública: queriam interpelar a sociedade, o Estado, a política, empenhavam-se para fixar uma dimensão pública no país e para estar presentes onde as coisas pulsavam e aconteciam. Evidentemente, nem todos estes pontos compareciam com igual peso em cada uma daquelas tradições: pesavam de modo relativo e se distribuíam irregularmente por elas, sendo mais fortes em umas e mais fracas em outras (em algumas tradições, por exemplo, há mais vocação pública que intenção científica, em outras é maior a presença da grande narrativa do que a perspectiva do projeto).

Seja como for, parece-me inegável que, quanto mais avançamos rumo ao final do século XX, mais nos distanciamos do padrão intelectual representado por aquelas tradições. Passamos a fazer ciência de outro modo: em muito maior quantidade e num ritmo bem mais veloz, mas também com bem menos paixão cívica (ou mesmo sem paixão nenhuma: movidos pelo cálculo, pelo custo-benefício). É neste fato que se assenta o mal-estar acima mencionado.

Por que ocorreu isso? Antes de tudo porque os anos 60 e 70 transcorreram sob o signo de uma perversa e complexa ditadura militar, que, com seus traços típicos (tecnocratismo, censura, repressão, desenvolvimentismo autoritário e anti-social), lançou o país numa onda modernizadora que represou e desqualificou tradições, fragmentou a sociedade, generalizou a competitividade, massificou repressivamente o ensino e alterou em profundidade a fisionomia cultural do país. Em decorrência, fomos forçados a pensar de outro modo, a cortar vínculos com o passado, a despolitizar o campo da produção intelectual, entrando em contato com uma indústria cultural que se impôs categoricamente sobre a sociedade. Criaram-se, assim, muitas importantes condições para que fôssemos pouco a pouco assistindo a uma reconfiguração dos próprios intelectuais: eles foram progressivamente deixando de ser intelectuais públicos. 
Fazendo uso (e um certo abuso, também) das posições do conhecido livro de Russell Jacoby, Os últimos intelectuais, creio ser possível dizer que estamos assistindo, e não de hoje, a uma espécie de agonia do intelectual interessado em se pôr em contato com o povo: não como portavoz de seus interesses, alguém que se sente imbuído de uma espécie de "mandato" para falar em nome dos despossuídos, dos explorados ou das forças vivas da nação, mas como seu organizador e seu dirigente éticopolítico, para falar em termos gramscianos. Ou seja, estamos perdendo o intelectual interessado em dialogar com a sociedade, em ser por ela compreendido, em se comunicar com ela, ou com a parcela mais educada dela, que seguramente não é uma parcela especializada. Em vez disso, o mundo atual parece forçar o intelectual a se especializar unilateralmente, conforme padrões de exigência intelectual que ele não controla, e que o levam a codificar sua linguagem, a se fechar em códigos esotéricos e imperscrutáveis pela grande massa. Paradoxalmente, este intelectual hermético, que não se comunica ou se comunica mal, também funciona como uma espécie de enfant gâté da mídia, que o procura como fonte de legitimação ou "prova" das notícias e dos comentários cotidianos. De um modo ou de outro, tratase de um intelectual que se liga ao público sem ser um intelectual público: os vínculos fortes deste intelectual, hoje em dia, são estabelecidos, na verdade, com seus pares e com a rede institucional em que se atua. Pautado pela grande mídia, o intelectual acaba por ajudar a que se produzam mais informações, mas não distribui conhecimentos.

\section{DESENCANTAMENTO E CRISE DA CULTURA ACADÊMICA}

Temos aqui, portanto, um efeito derivado da própria cultura dominante, que está cortada, como sabemos, por fortes tendências tecnicistas, que poderíamos associar à vitória de um tipo próprio de racionalidade, a racionalidade instrumental. Max Weber ficou justamente famoso ao reconhecer que o processo de racionalização crescente típico das sociedades ocidentais modernas trouxe consigo uma cultura que impõe sacrifícios enormes ao pensamento, à política, à convivência comunitária, na medida mesma em que "despoja o mundo de magia" e submete todos os atos, todas as decisões e todos os focos de vida associativa ao ritmo da racionalidade instrumental, do cálculo, da burocratização. Nesta situação, todos passam a ter de despender grande energia para conseguir controlar ou domesticar a razão técnica. Acontece isto com os intelectuais dos nossos dias. Como em todas as 
demais áreas, também na vida intelectual o critério passou a ser o máximo de eficiência, a melhor relação "custo/benefício". Instituições, pessoas, relações, valores e idéias, tudo se converte em instrumento de nossos interesses, projetos pessoais e ambições. Neste tipo de racionalidade, valores quentes e ideologias não são bem-vindos e as "grandes narrativas" - os esforços totalizantes, dedicados a fornecer explicações abrangentes, integradas, organizacionais - são rejeitadas em nome da necessidade de se conhecer mais coisas, ou de se conhecer em termos imediatamente operacionais, ou de se fundar uma nova e original zona de pesquisa, ou de se pensar de modo mais pragmático, o que muitas vezes significa aceitar pautas e procedimentos exteriores à lógica do pensar teórico ou artístico, ditados por agências de financiamento, estatutos burocráticos ou meios de comunicação.

É evidente que estamos aqui às voltas com o tema weberiano da racionalização e da burocracia: o mesmo desencantamento que "despoja o mundo de magia", desloca os valores últimos para regiões nebulosas, aquém da esfera pública. Se olharmos bem as instituições em que produzimos boa parte de nossas idéias (onde pensamos) - as universidades, em particular -, não teremos qualquer dificuldade para perceber como elas ficaram encharcadas de burocracia, de rotinas formais, de incentivos que empurram o pensamento crítico para a periferia dos sistemas. O intelectual acadêmico, hoje, é um ser burocratizado, envolvido por um circuito de congressos, seminários e reuniões que o sobrecarregam de atividades pouco produtivas e o forçam à especialização, ao abandono da "grande narrativa", à produção em série de papers e artigos homeopáticos.

A figura do intelectual acomoda-se com dificuldade num mundo dominado por estruturas burocráticas e racionalidades instrumentais. $\mathrm{O}$ problema se agrava quanto mais pobre é a luta política e ideológica que se desenrola na sociedade. Se se rasteja em termos políticos - se não se sabe bem contra quem se luta ou a favor de quem se toma partido, se há pouca transparência e consistência no conflito, se falta densidade e civismo à linguagem - o debate intelectual fica impelido a se isolar do restante e a se codificar. Mas deveria haver mais empenho para limitar os efeitos desta situação. Se é verdade que, ao longo dos últimos trinta anos, os intelectuais perderam progressivamente a possibilidade de continuar concentrando o papel de produtores de sentido para a sociedade, não é inevitável que eles se entreguem sem mais nem menos à tarefa de demolir as chances de manter algum diálogo com as pessoas e ser por elas compreendidos. Não faz muito sentido ter um público sem se preocupar em falar para o público e ser um intelectual público. 
A cultura acadêmica, além do mais, parece ter perdido parte da fé em si mesma. Contorna a polêmica, foge do debate direto, evita os temas mais explosivos e se entrega sem pruridos a uma agenda temática sempre cheia de novidades, metodologicamente correta, composta por problemas e autores de fronteira, pós-modernos ou não. Alega, em seu favor, uma "crise de paradigmas" não muito bem compreendida, algo que obrigaria $o$ pesquisador a cultivar o ecletismo, a recusar temas mais tradicionais ou clássicos, a minimizar as reconstruções históricas, a insistir no diálogo com o dernier cri do mundo global. Na outra ponta, subsiste uma cultura alternativa generosa, fiel às melhores utopias, mas que muitas vezes se fecha doutrinariamente nos mesmos temas de sempre, em nome de uma coerência teórica que com freqüência resvala para o dogmatismo e se mostra com dificuldade de se renovar. Embaralhada pelas pressões advindas do contexto intelectual mais amplo - onde se cruzam pensamento único, pósmodernidade, tecnicismo e especialização -, pelas rotinas da burocratização e pelos condicionamentos derivados dos novos vínculos que se estabeleceram entre os intelectuais e a política (tantos os com o poder e o governar, quanto os com os movimentos sociais), a cultura acadêmica tem dificuldades para se afirmar e mesmo para se reproduzir. Pairando sobre tudo, aquele que parece ser o fato cultural mais relevante dos últimos tempos: a perda de prestígio do marxismo, esta grande proposta teórica voltada para a totalização dialética, a historicização, a crítica radical, a reposição plena das subjetividades na história, fato que desfalca a vida intelectual de um importante parâmetro e de um propulsor fundamental.

Os ambientes acadêmicos ficam, assim, sem a presença do "contraditório" e tendem a se homogeneizar. Abre-se um vácuo, que comprime o pensamento crítico e constrange o livre debate de idéias. Neste quadro, o pensar acaba por ser atropelado ou por um certo tipo de ativismo produtivista, ou por um movimentismo doutrinarista: deve-se fazer coisas sem parar, participar, falar, escrever, estar em circulação incessantemente, denunciar sempre, indignar-se perante todas as falhas e injustiças. De um modo ou de outro, fica-se compelido a girar, a agitar, a realizar, quase sempre em prazos estranhos ao ritmo "natural" da produção intelectual. Ainda que repletas de incentivos importantes para a dinamização das instituições, estas são atitudes que roubam o eixo do pensamento crítico e acabam por redefinir a idéia mesma de mérito, deslocando-a para um plano mais secundário ou mais impreciso. Maior indicação disso é que hoje, dentro das instituições, prevalece um imaginário construído por picuinhas departamentais, retóricas inflamadas, lutas por posições administrativas e glórias fugazes. 
Arma-se aqui um mix de determinações: a força devastadora da burocracia se articula com uma queda brusca na qualidade do imaginário acadêmico e com uma relação estranha e enviesada dos intelectuais universitários com a política - com o Estado, os governos, os partidos - e com o mercado, processo que provoca uma espécie de "fuga" de cérebros e insere, no cotidiano institucional, uma lógica torta de cobranças, denúncias, instrumentalizações e alinhamentos artificiais.

Creio decorrer de tudo isso o fato de que, nos últimos tempos, em muitos debates, se tem falado de quase tudo, menos do fundamental. Este aparece nos textos como um corpo estranho, embrulhado em ajustes de contas, questões subentendidas, citações refinadas, algumas futricas e baldes de exibicionismo. No final, fica-se com a sensação de que algo se perdeu. Sequer o confronto de idéias se completa, porque cada contendor sempre é visto com suspeita e sempre se oculta, como se estivesse obrigado a esconder seus pontos de vista ou suas afinidades eletivas. Não há mais, portanto, pensamento, apenas remissões bibliográficas, críticas pessoais e apoios velados.

\section{VETOS, APOSTAS E DICOTOMIAS}

Tentando agora chegar mais perto do tema central da presente discussão, gostaria de sugerir algumas hipóteses para que se imagine a organização de um mapa do "como se pensa" no Brasil dos dias de hoje. São hipóteses preliminares e apenas esboçadas: mais um roteiro provocativo que um conjunto de conclusões categóricas. Estão concebidas não tanto para investigar como o mundo acadêmico pensa, mas para perscrutar a cultura hoje prevalecente, o modo como as pessoas em geral - do "homem comum" aos formadores de opinião, dos políticos aos técnicos governamentais pensam a realidade em que vivem. A universidade é parte da vida, mas ainda que não escape totalmente do quadro geral, insere-se nele e dele recebe influências através de múltiplas e complicadas mediações.

Arrisco-me, assim, a dizer que nosso panorama intelectual está estruturado por três vertentes problemáticas, todas nascidas do quadro acima sugerido e por ele alimentadas. São vertentes que se cruzam e se combinam de muitas maneiras, intercambiando reciprocamente seus traços típicos. Temos, em primeiro lugar, um conjunto de vetos satanizadores: ao Estado, à política, à globalização, às ideologias. Este é um espaço dilatado, em que acampam descrenças e denúncias, desqualificações categóricas e 
menosprezo. A linguagem predominante, aqui, fala de inconveniências e excessos do Estado, instituição que, num quadro tomado pela complexidade, pela incerteza e pela nova economia, não teria mais como deixar de ser eminentemente repressora do empreendedorismo societal: um fardo, que a sociedade não deveria mais carregar. Fala, também, de falhas e imperfeições estruturais da política, que se mostraria tão despreparada para conviver com a nova sociedade da informação que se tornaria mesmo dispensável: um ônus, que a sociedade não deveria mais pagar. A globalização, por sua vez, é tratada com desprezo ou banalizada. Dado o elogio apologético que muitos fazem da reorganização globalizada da vida mundial, acredita-se que seria indispensável retirar toda a dignidade da globalização: não estaríamos diante de nenhum fato novo, mas apenas diante de uma faceta mais desencarnada do mesmo velho sistema capitalista de sempre. Quanto às ideologias, bem, estas não fariam mesmo mais nenhum sentido, e só atrapalhariam, na medida em que estimulariam o "extremismo" em nome de velhos ideais cansados e quase sempre "rançosos", exaltados, "zangados". Falo aqui, como é evidente, de ideologias como fato ontológico, como força real: não como "falsa consciência", mas como conjuntos mais ou menos sistemáticos (mais ou menos "orgânicos", no léxico de Gramsci) de proposições que expressam as aspirações de correntes históricas, grupos ou classes. Ideologias, portanto, no sentido de projetos: proposições que direcionam e movem pessoas, sujeitos individuais ou coletivos. Seríamos melhores hoje, dizem, porque conseguimos nos tornar menos ideológicos: livramo-nos das ideologias, com suas inevitáveis patrulhas. Estaríamos usufruindo os efeitos de uma vitória da razão sobre a paixão.

A segunda vertente seria composta por um conjunto de apostas endeusadoras: nas virtudes da sociedade civil, na força renovadora e democrática dos novos movimentos sociais, na ética. A linguagem, aqui, é francamente positiva e em certa medida ingenuamente otimista: aposta-se naquilo que configuraria a novidade máxima, que estaria "solto" em relação à política tradicional e que, por isso, estaria encharcado de virtude. Se, por um lado, a ética tende a assumir o posto de comando e a condição de parâmetro geral, por outro lado é para a sociedade civil que se voltam todas as atenções e todas as energias. Neste ponto, porém, mergulha-se numa zona cinzenta e nebulosa. A sociedade civil de que se fala aqui ainda quando eticamente pensada como progressista e libertária - não está bem posicionada. Ela não é a sociedade civil gramsciana - democraticamente politizada, interessada em viabilizar a passagem "catártica" dos 
interesses particulares para uma esfera mais "universal", em construir hegemonias e re-fundar o Estado -, mas uma sociedade civil de tipo neoliberal: despolitizada, composta para viabilizar os interesses particulares e para compatibilizar Estado e mercado, para se opor ao Estado não para refundá-lo, mas apenas para arrancar "vantagens" dele. Um novo espaço público, não-estatal.

A terceira vertente, por fim, seria integrada por uma série de reiterações, boa parte das quais derivadas da primeira vertente. Reitera-se, antes de tudo, uma visão reducionista do Estado, que é visto apenas como um instrumento de intervenção, um aparato administrativo, ou basicamente como recurso de governo. Reitera-se, depois, uma concepção negativa da política e da institucionalidade política, vistas, ambas, essencialmente pelo seu lado "negativo", mais afinado com a manipulação, o arbítrio, a malícia e a força, sem muita consideração para com sua dimensão positiva. Reiterase, ainda, um tratamento fundamentalista e catastrofista da globalização, que traria consigo um cortejo de desgraças e nenhuma positividade, devendo ser por isso categoricamente rejeitada.

Reitera-se também, num segundo momento, um modo dicotômico de pensar: um pensamento que opera por contraposições rígidas, congeladas, maniqueístas, que por si mesmas desestimulam qualquer totalização.

\section{DESCORTINAM-SE TRÊS DICOTOMIAS PRINCIPAIS}

A primeira é a dicotomia entre técnica e política: valoriza-se unilateralmente o saber técnico em detrimento do saber político, da sensibilidade política e da face "quente" da política (a face dedicada à formação de identidades, à organização de paixões e projetos coletivos). Trata-se de um dado inerente à cultura da época. Não é por acaso que, no Brasil e no mundo, hoje em dia, todas as honras e glórias são dirigidas para o centro, um espaço hipoteticamente mais "equilibrado", menos "ideológico" e "passional", mais predisposto a se adaptar aos contextos "duros" da globalização, mais interessado em assimilar as vantagens e os ritmos da cultura técnica e da tecnologia. Em decorrência, cristaliza-se, no pólo oposto, uma visão politicista e doutrinariamente antitécnica, avessa portanto à necessidade de absorver conhecimentos técnicos e de pensar tecnicamente a política, o governar, o organizar.

Passa-se o mesmo com a segunda dicotomia, a que opõe normas e sujeitos: ou se valoriza unilateralmente a organização - em nome da necessidade imperativa de ordem, regras, controles -, ou se hipostasia o 
sujeito em nome da sua necessária e plena liberação. Na primeira hipótese, sufoca-se a diferença e a contradição; na segunda, perde-se o momento coletivo, organizacional. Ou se cancela o conflito em benefício da tranqüilidade sistêmica, ou se chega perto do caos em favor da liberdade ou da ação anti-sistêmica. De um modo ou de outro, fica-se sem poder fundamentar uma sociabilidade de novo tipo, solidária e democrática, na qual todos possam coexistir como sujeitos.

O reconhecimento do sujeito é chave de muita coisa. Serve, acima de tudo, para colocar em outras bases o fascínio que a força das estruturas exerce sobre as pessoas. Se pensarmos bem, veremos que não existe o "social", a "sociedade", como se macro-corpos abstratos conduzissem nossas vidas e agissem por conta própria. Grupos e indivíduos "fazem-se uns aos outros", como Marx e Engels escreveram na Ideologia alemã, e da dinâmica deste fazer recíproco nasce a sociedade, a história. Trata-se, pois, de um jogo de projetos que interagem uns sobre os outros e criam uma dinâmica na qual uns prevalecem sobre outros. O reconhecimento do sujeito também nos coloca de outro modo diante do problema da liberdade, do desejo, das vontades e dos interesses. Até onde as estruturas determinam ou podem restringir o sujeito e sua liberdade? Como pensar a questão da limitação e das escolhas? São temas que naufragam num mar de imprecisões, se não vierem acompanhados da consideração do vasto campo das subjetividades, bem como sem a consideração da dialética autonomia-determinação, ou, como dizia Gramsci, das relações entre liberdade, responsabilidade e disciplina. O fundamental, no caso, é buscar compor planos constitutivos de nossa própria existência. Se renunciarmos à liberdade (ao desejo, ao interesse, à vontade), nos negamos a nós mesmos: deixamos de ser sujeitos autônomos e não teremos como viver bem a vida. Mas, por outro lado, se não soubermos abrir mão de parte de nossos desejos e interesses, se não soubermos ceder em nome de certos compromissos e projetos coletivos, não teremos como viver em sociedade (grupo, organização) e não teremos como ser efetivamente autônomos.

A terceira dicotomia contrapõe o social ao institucional, e caminha na mesma direção. Em certo sentido, ela se confunde com a contraposição funcionalista do Estado à sociedade civil, que concebe ambas estas instâncias como separadas categoricamente, incomunicáveis, reduz o Estado a uma instância concentrada no "mal" (o poder, a força, a coerção), ao passo que projeta a sociedade civil como a expressão cabal do "bem": uma ética em ação. Dada a hegemonia neoliberal sob a qual vivemos, tal dicotomia acaba por incentivar a que a questão do Estado seja quase sempre pensada pela ótica do tamanho e do custo do Estado - pela ótica do 
"ônus" que o Estado causa à sociedade. Trata-se de uma visão que ganhou foros de "pensamento único" e encontra adeptos da direita à esquerda, contagiando até os que lutam contra o neoliberalismo, que passam muitas vezes a assimilar aquilo que combatem, isto é, a também descartar o Estado e a institucionalidade política. Neste último caso, modifica-se apenas o lugar e o peso relativo dos termos: a rejeição do Estado não se faz mais em nome do mercado, mas em nome da cidadania ou da "sociedade civil".

Este modo de pensar o Estado impede, em boa medida, que a questão social e a questão institucional se integrem na agenda nacional: as propostas de reforma social ficam distantes de uma opinião forte a respeito do Estado. O situacionismo, por um lado, jamais explica para que servirá de fato a reforma do Estado que acalenta, procedendo como se ela contivesse, em si mesma, um mérito inquestionável e pudesse, por isso, ganhar preeminência inconteste sobre a questão social. O oposicionismo, por sua vez, atribui à política (ao Estado) a culpa pelas mazelas sociais, mas não pensa a política (o Estado) como recurso para combatê-las. De um modo ou de outro, o campo da política - campo onde se explicitam as condutas, as convicções, as regras e as instituições com as quais se organizam a convivência e a dominação, o governo e a oposição, o consenso e o conflito, a coerção e a hegemonia - acaba por ser desvalorizado.

A incidência prática deste modo de pensar o institucional e o social é evidente por si só. Cria muitos desajustes e paralisias. Deixando de examinar com rigor a questão do Estado, os atores políticos ficam impotentes para alcançar uma idéia revigorada de pacto político ou projeto nacional. Os partidos políticos tendem a agir de modo errático, pouco produtivo, sem um curso muito claro, pautados pelo calendário eleitoral, por aquilo que faz ou deixa de fazer o governo, pelas demandas e pressões dos movimentos sociais. Perdem identidade, protagonismo e capacidade de direção. Tornam-se meio subalternos, pouco relevantes. Os movimentos sociais, por sua vez, tendem a se descolar de partidos e instituições, a forjar uma "legalidade" e uma "institucionalidade" próprias, desinteressando-se de formular projetos de hegemonia, isto é, projetos que contemplem toda a sociedade e se traduzam em respostas e perspectivas para os diferentes grupos sociais.

\section{PENSAR O MODO DOMINANTE DE PENSAR}

Se este quadro pode ser minimamente reconhecido como razoável, a conclusão a que se chega é que, hoje, se nos posicionarmos com 
os olhos no futuro, no homem como ser que responde e pode projetar, estamos obrigados a fazer a crítica do modo dominante de pensar. Tratar-se-ia de alcançar uma crítica no sentido rigoroso da expressão, ou seja, algo categoricamente distante de qualquer dogmatismo ou fechamento doutrinário: não apenas uma recusa ou uma negação, mas também uma superação e uma incorporação. Deveríamos criticar o modo dominante de pensar para colocá-lo em um nível superior, retendo e expandindo o que há nele de positivo e útil (como seria o caso, para ficar no exemplo mais fácil, do aproveitamento dos novos conhecimentos, dos recursos técnicos disponibilizados, das novas abordagens metodológicas). Nos termos em que se desenvolveu a argumentação no presente texto, este esforço crítico passaria pela resposta a algumas questões pontuais. Como promover o reencontro entre técnica e projeto, estabelecendo um outro modo de ligar os recursos técnicos e a tecnologia à política, quem sabe domesticando-os e democratizando-os? Como repor dialeticamente a idéia mesma de projeto, e particularmente de projeto nacional, num contexto que é categoricamente transnacional e não oferece mais suporte para visões autarquizantes de nação? Como atualizar a tradição da "grande narrativa" num mundo que fragmenta e estilhaça, que nos sufoca com informações e nos convida incessantemente a separar, a minimizar, a buscar o detalhe isolado? Como recuperar a capacidade mesma de ir à raiz das coisas, de ser radical, num circuito que tende ao relativismo, impõe a "flexibilidade" como critério geral e hipervaloriza as "adaptações"?

Isso significaria ligar o "como se pensa" ao "como pensar" e mesmo ao "por que pensar?", enfoques que compõem a estrutura do presente seminário. Neste sentido, e tendo em vista o exposto, diria que estamos obrigados a pensar de novo em termos dialéticos, não só para fazer a crítica teórica (a crítica das teorias e dos posicionamentos teóricos), mas para fazer também a crítica do real, ou seja, compreendê-lo de modo abrangente, totalizante, como "síntese de múltiplas determinações". Não se trata, porém, aqui, de uma mera reposição, como se a dialética pudesse se alimentar só de puro Marx ou puro Hegel, sem qualquer acréscimo ou inovação. Se o mundo tornou-se mesmo global - isto é, mundializou-se categoricamente e viu suas áreas específicas integrarem-se sempre mais —, não temos como apreendê-lo sem tratá-lo como um complexo, um todo que é tecido junto. Isso requer uma inteligência especial: em vez de procedimentos que separem e isolem, precisamos de perspectivas que integrem, organizem e totalizem. Só assim teremos como aproveitar de modo pleno as inúmeras possibilidades de compreensão e reflexão propiciadas pela evolução geral dos conhecimentos. 
Afinal, pensar em termos complexos significa recuperar e atualizar com alguma radicalidade o pensamento dialético do século XIX — o de Marx, sobretudo —, ampliando-o com a incorporação das conquistas teóricas do século XX (a física, a microbiologia, a genética, a ecologia, a inteligência artificial) e com uma dose adicional de 'modéstia' intelectual. Trata-se de uma 'modéstia' inerente à natureza mesma do pensamento científico - que não pode se pretender onipotente ou imbatível — e que de algum modo se associa à própria maneira como o mundo foi-se reorganizando nas últimas décadas.

Tudo isso significaria, no fundo, reaproximar o momento intelectual do momento político, o "como se pensa" do "mundo de todos". Tanto a crítica do modo dominante de pensar e de travar a luta ideológica, quanto a recuperação criativa do espaço mesmo do pensamento, são operações que integram, em lugar de destaque, um programa de "reforma intelectual e moral" (Gramsci), inserindo-se portanto na batalha cultural que acompanha a luta política e com ela se confunde. 



\title{
UM PACTO CONTRA OS ENCLAVES DE DESPOTISMO
}

\author{
LUIZ EDUARDO SOARES
}

Em primeiro lugar quero me congratular com os colegas do CEDEC pelos 25 anos. É uma honra ter tido o privilégio de ser convidado e poder participar dessa celebração, um debate. Entendi que se esperaria de mim uma reflexão sobre o que está pensando nessa área na qual eu tenho trabalhado, ligada à violência, à criminalidade, à segurança pública. Talvez seja ainda mais interessante refletir sobre o que não se está pensando sobre esses problemas. Digamos, por hipótese, que fosse verdadeiro os seguinte fato: que três milhões de brasileiros no eixo Rio/São Paulo vivam sem acesso ao Estado de direito. E não estou me referindo aos benefícios da democracia no seu sentido amplo, nem às suas dimensões substantivas, se quisermos adotar aquela dicotomia superficial mas indicativa. Eu me refiro mesmo àquelas liberdades fundamentais de ir e vir, de se expressar, de se organizar, de se organizar politicamente. É a isso que esses três milhões não têm acesso. Se um enunciado como esse (e haveria muitos outros no mesmo sentido) se revelassem verdadeiros seríamos levados a nos indagar sobre o próprio processo da transição para a democracia.

Quero propor que se considere a hipótese de que esse enunciado seja verdadeiro e de que, portanto, devêssemos contemplar questões como essa nas nossas reflexões sobre o processo político contemporâneo no Brasil. Isso significaria que vivemos no campo político e institucional uma espécie de simulacro da experiência identificada, nos termos clássicos marxistas, como desenvolvimento desigual e combinado. Seríamos levados a crer que o processo de transição não se cumpriu. Por outro lado, é também verdade que o processo se cumpriu. Temos instituições democráticas funcionando, operando, se reproduzindo, oferecendo condições legais de sua ampliação, de sua transformação. Talvez fosse mais apropriado considerar real essa duplicidade, essa ambivalência ou ambigüidade, e a idéia do desenvolvimento combinado e desigual propi- 
ciaria a oportunidade para considerarmos verdadeira a hipótese desse convívio tenso e contraditório. Então eu poderia enunciar a seguinte tese. $\mathrm{O}$ processo de transição evidentemente se cumpriu. Produziu seus efeitos, seus resultados, por mais limitados que fossem, mas se cumpriu. Por outro lado, não se cumpriu, e ainda está em curso.

\section{AUSÊNCIA DO ESTADO E DUPLO DESPOTISMO}

Vivemos num universo político muito contraditório. Consideremos o caso do mercado informal. Quando atentamos para as limitações do Estado brasileiro talvez tivéssemos de associar essa não extensão do Estado de direito a três milhões de brasileiros às dificuldades que o Estado tem de regular o trabalho e de oferecer aos trabalhadores os direitos sociais. Isso significa que tudo se dá como se tivéssemos enclaves, vários enclaves de ausência do Estado. Isso é curioso, porque na tradição política o coronelismo em certo sentido também significava esse tipo de articulação desigual, com enclaves integrados numa lógica que subsumia as dinâmicas subordinadas. No entanto o coronelismo representava uma espécie de enclave delegado, e nesse sentido era funcional. Era como se a institucionalidade suspendesse a sua vigência mas incorporasse um interlocutor, um agente, que em nome da institucionalidade dominante produziria ali alguma forma de ordem derivada. No caso contemporâneo, no lapso do Estado ao qual eu me referi, vigente no Rio e São Paulo, teríamos uma situação muito diversa, porque não há delegação e há no mínimo disfuncionalidade, ou contradição. Refiro-me aos três milhões de brasileiros, paulistas e cariocas, que vivem nas 600 favelas do Rio e nas periferias de São Paulo. (Esse número não é muito preciso, é mais alusivo à magnitude do processo).

$\mathrm{O}$ que de fato ocorre nas favelas do Rio e em algumas periferias, pelo menos de São Paulo, é o domínio territorial de grupos armados que impõe seus códigos, impedindo, portanto, o exercício da democracia no seu sentido mais elementar. Vou dar-lhes dois exemplo, triviais para quem vive no eixo Rio/São Paulo, mas nunca é demais reforçar a memória com um dado de realidade. Na favela do Guarabu, na Ilha do Governador, há cerca de três meses, um trabalhador, um rapaz de 32 anos, foi procurado à noite por traficantes para guardar armas em sua casa. Ele se recusou a fazê-lo, para proteger seus filhos. No dia seguinte os traficantes foram buscá-lo, quebraram suas pernas, seus braços, furaram seus olhos e depois o mataram. Isso só para que saibamos do que estamos falando. Um outro exemplo: quando 
houve uma ocupação policial e social da área do Complexo da Maré, que é um conjunto de favelas do Rio de Janeiro, uma ocupação supervisionada, com respeito aos direitos humanos, em que o policiamento procurava repetir o método adotado na Zona Sul do Rio de Janeiro, o presidente da Associação local me procurou emocionado (na época eu desempenhava um papel na Secretaria de Segurança) para agradecer em nome da comunidade. pedir que a nossa parceria tivesse continuidade. "Ontem eu abri as janelas e nós pudemos colocar algumas cadeiras na frente de casa e conversar com os vizinhos", disse ele. Abrir a janela é alguma coisa profundamente significativa para uma população que vive sob regime do terror, que não pode respirar, que tem de usar certas camisas, sair de casa em certos horários e que está sujeito às torturas, aos assassinatos mais cruéis e arbitrários, e que não conta com o apoio do Estado, porque em geral a Polícia que serve essas áreas está ligada ao crime e é tão criminosa ou mais que os bandidos. Na realidade o que temos aí é um duplo despotismo.

\section{ENCLAVES E POLITIZAÇÃO}

Portanto, quando falamos de violência pública, de criminalidade, talvez estejamos falando no Brasil de alguma coisa mais grave, mais profunda, com grande significado social, político, institucional. Estamos falando desses enclaves em que a institucionalidade democrática não vigora. Nesses termos toda a questão referente à credibilidade, à confiança, à eficiência do trabalho policial, converte-se em tema central tão relevante quanto os temas institucionais políticos usuais e tradicionais.

Por outro lado, temos um contexto político que hiperpolitiza a questão da segurança pública. Como reação a essa hiperpolitização e às suas consequiências perversas cheguei a defender publicamente uma posição da qual hoje discordo. Naquela ocasião eu tinha em vista que a hiperpolitização significa o seguinte: como as mortes são cotidianas, 16, 17 por dia no Rio, há sempre um repertório muito grande de tragédias e, portanto, um repertório sempre muito grande de material para instrumentalização política. Se as forças políticas não têm nenhuma responsabilidade pública, se elas estão inteiramente animadas pelo auto-interesse e pelos projetos partidários e segmentados como costuma acontecer na lógica da disputa, o que ocorre é que cada tragédia dessas alimenta o circuito predatório da disputa, do conflito, não permitindo que o governo tenha qualquer espaço de manobra ou uma trégua para reorganização do sistema. $\mathrm{O}$ 
efeito perverso é óbvio, destrutivo para todos, porque quem herdar o caos vai ser condenado a repetir a mesma sina, que se converte numa espécie de destino político. Então eu cheguei a imaginar, equivocadamente, a criação de uma institucionalidade autonomizada dessa disputa, quando na realidade o correto seria então radicalizar essa politização e convertê-la em objeto da disputa pública com transparência. Esse seria o caminho correto e eu acho que talvez isso nós possamos e devamos fazer. Isso poderia conduzir-nos a que quem sabe a única forma de virada de fato desse jogo e de conclusão do processo de transição: um grande pacto, uma grande unidade entre todas as forças políticas que de fato têm algum compromisso com a democracia. Fora de um pacto suprapartidário de grande alcance talvez não tenhamos nenhuma chance de avançar nessa área.

Isso não é matéria exclusivamente para o Rio de Janeiro, onde é claro que tem consequiências imediatas, mas talvez seja matéria para reflexão também no âmbito nacional. Temos aí alguns temas e alguns problemas que talvez nos levem a refletir sobre a própria natureza do Estado brasileiro e do nosso processo contemporâneo. 


\section{DEBATE}

BOAVENTURA DE SOUSA SANTOS - Ouvindo ontem o Werneck e o hoje o Renato e o Marco Aurélio, a idéia que eu tenho é que os problemas do Brasil e do pensar o Brasil não são apenas do Brasil, os problemas que eles analisaram nas suas exposições são problemas hoje mundiais. Eu estava a ouvir o Marco Aurélio e a ver a discussão que temos hoje na Europa. Eu na semana passada estava na Colômbia, num debate sobre as ciências sociais, onde esta temática era também assim tratada. Portanto o que eu penso de fato é se hoje nós não devemos discutir as coisas não apenas ao nível do pensar Brasil, mas pensar o continente e espelhar, pensar o mundo. Foi sempre uma deficiência no pensamento brasileiro, não pensar o continente. Talvez por ser um continente ele próprio, teve dificuldades em pensar o resto do continente latino-americano. Todas as tradições que vêm do Nuestra America, de José Marti, por exemplo, que exposição tiveram aqui? Isso tem a ver com o projeto nacional de que falava o Octavio Ianni. De maneira nenhuma estou contra projetos nacionais, como no debate que temos neste momento em Portugal, no contexto da União Européia. Mas como pensar um projeto nacional num contexto pós-nacional? Essa é a grande questão. É evidente que há um lugar para cada um desses países mas que lugar é esse nesse contexto transnacional? No momento em que a ALCA está a avançar sem qualquer debate no Brasil, ou com muito pouco debate no Brasil, eu penso que há um projeto nacional que está na forja, que está a ser pensado, e que se calhar as ciências sociais estão distraídas em relação a esse ponto.

Por outro lado, ao ouvir Luiz Eduardo Soares, realmente é impressionante a apresentação de dados, também me parece que os problemas não são apenas brasileiros nesse momento, porque eu penso que ao nível do continente nós encontramos hoje muitas cidades - Cidade do México é um exemplo, Bogotá e Medelin, e tantas outras - onde temos esse problema. Enfim há sempre diferenças, mas o grande problema para nós, em ciências sociais, será ver o que é específico e o que é realmente comum nas problemáticas. Gostava de atentar e propor para debate a idéia, que 
tenho vindo a defender, de que o realmente novo na situação e não específico a nenhum país é que nós vamos cada vez mais viver em sociedades em que estados democráticos convivem com sociedades fascísticas. Isto é, o Estado não é fascista, o Estado é democrático; a sociedade é que é fascista, e o Estado colabora, é cúmplice, umas vezes mais outras vezes menos, com esse apartheid social de que falava, com os enclaves de que falava Luiz Eduardo Soares. É o que eu chamo realmente de fascismo social. E o Estado democrático tem essa característica: atua democraticamente nas zonas civilizadas, digamos, nas zonas onde há direitos e onde as populações estão protegidas, e atua fascisticamente nas zonas, digamos, dos tais enclaves! É o mesmo Estado, é a mesma Polícia, são as mesmas academias de polícia, não precisa de outra institucionalidade. Na nossa tradição sempre olhamos para o fascismo como um regime político e ele hoje é um regime social. É por isso que a democracia é compatível com o capitalismo: o fascismo está socializado e a democracia está formalizada no Estado.

$* * *$

TULLO VIGEVANI - Com relação ao tema da violência, de que falou Luiz Eduardo Soares, provavelmente, a sociedade e os grupos mais pobres da população não vivam com o sentimento permanente de um clima de terror social. Poderia haver uma articulação e uma agregação ao redor de novos valores, em que essa marginalidade produza um novo tipo de sociabilidade. Cito Aníbal Quijano, que faz esse tipo de análise em relação ao caso peruano e de Lima, mas que, diria, tem elementos de validade em nível continental muito significativos. Aqui sim, há uma especificidade latinoamericana. Os outros processos de outras regiões, também pobres, asiáticas ou africanas, são diferentes. Podem até ser mais graves, do ponto de vista da pobreza - é o caso da África -, mas o tipo de agregação social e o tipo de valores pelos quais se sociabilizam as pessoas são diferentes.

Renato Lessa e Marco Aurélio Nogueira fizeram um bom diagnóstico, mas faltou esboçar a resposta a uma pergunta. A pergunta é: por quê? Por que as ciências sociais se voltam para a análise atomizada e para a análise das pequenas coisas, como colocou Renato Lessa, ou por que as ciências sociais, no caso da interpretação de Marco Aurélio Nogueira, se tornam burocratizadas e institucionalizadas no sentido negativo da palavra? Concordo com que hoje estamos, não só no Brasil, numa condição de dificuldade para o desenvolvimento de uma teoria crítica. Não há uma força nesse sentido, não há um input para acordos nessa direção. Provavelmente, 
como disse Marco Aurélio Nogueira, estamos sem visões de longo prazo. Provavelmente as grandes idéias, mesmo as grandes idéias no campo da teoria política e da teoria social, tenham se produzido nos momentos históricos de grandes tensões, que geram grandes visões. Renato Lessa citou os nossos clássicos. Todos eles produziram sua obra à luz das necessidades do seu tempo e sob o impacto dos grande embates e da necessidade de produzir idéias novas, respondendo a esses mesmos embates. Esse aspecto - o da necessidade de idéias - talvez seja o problema do mundo de hoje. Um mundo que sai de um século que assistiu à crise da extrema direita, do nazismo, e assistiu à crise, no meu entender mais trágica, do stalinismo. Crise mais trágica porque sinalizou o vazio de uma proposta vista como possibilidade de esperança, por isso mais grave do nosso ponto de vista. Esta falta de perspectiva política acaba dificultando a possibilidade de formação de idéias, mesmo no campo da teoria.

$$
* * *
$$

LUIZ JORGE WERNECK VIANNA - Pensar é muito mais rico do que falar. Quando falamos estamos selecionando, ocultando uma parte do que pensamos. Eu acho que na primeira parte da mesa houve uma ênfase muito forte numa denúncia de um estado de coisas real. Agora, há outro lado da Lua, que não foi mobilizado. O outro lado da Lua é o seguinte: a sociedade se democratizou, as ciências sociais se democratizaram, sua clientela é outra. Inclusive o minimalismo dos temas, dos objetos, a própria necessidade do método se tornar uma realidade mais presente na nossa formação, derivam de uma ciência social democratizada. Então essa ciência social democratizada está em oposição à outra? Acho que não. Temos que pensar os dois lados. É perfeitamente possível conceber isso, de um lado a constituição de uma narrativa sobre o país, que seja capaz de enfrentar o dissídio do Brasil atual com a sua memória, sem o que não haverá alternativa para enfrentar politicamente o desvario em que esse país se tornou. Não vai ser a coleção de máquinas desejantes, da maximização dos desejos de cada qual que vai dar a solução. Há um problema que não vai se resolver no terreno da moralidade, que só pode se resolver no terreno da eticidade, e da eticidade concebida no plano da esfera pública. E uma ciência social que esteja a serviço, a serviço dos sindicatos, a serviço dos partidos, a serviço das instituições.

A universidade, o pensamento, podem conhecer todas essas dimensões, vai depender de como nós concebemos tudo isso. Mas também 
há o fato de que vimos a nossa institucionalidade ser definida no tempo da ditadura pelas fundações estrangeiras e pelo Estado ditatorial: assim nasce a Anpocs, com a Ford e com a Finep, em 78, 79. Então, é verdade, a transição ainda não se concluiu. A nossa própria institucionalização deriva dessa má construção, na Anpocs e numa série de outras instituições. Vamos pensar em CNPq, a CAPES... Qual foi a quebra, qual foi a ruptura? Ainda há pouca gente envolvida, precisa aumentar o escopo da deliberação. Não é reflexiva a disciplina? Por que não reflete sobre si publicamente?

Apesar desse meu tom eu acredito no nosso cometimento, acredito nas ciências sociais brasileiras, há caminho para elas. Podemos, sim, ser os continuadores dos nossos maiores, que num certo momento formularam um projeto para o Brasil.

$$
* * *
$$

RENATO LESSA - Meu primeiro comentário diz respeito a uma questão posta por Octavio Ianni a respeito da fragmentação brasileira, que me fez pensar o seguinte. Usando uma metáfora talvez excessiva, falamos das doenças do pensamento. Talvez fosse caso de falar também de algumas doenças do objeto, e sugerir uma "quarta mesa". Seria sobre o que se pensa, uma dimensão ontológica na nossa conversa além do como se pensa e do que

Essa é a maneira interessante de pôr o tema da fragmentação. $\mathrm{O}$ objeto sobre o qual nos debruçamos tem problemas graves, e nesse sentido eu penso o tema da fragmentação como marcado por duas fases - na verdade são duas fragmentações. A fragmentação que o Oliveira Vianna indicava diz respeito à idéia de uma sociedade insolidária, o insolidarismo vem da colônia e que tem aspectos de dendrofilia: o brasileiro como sujeito que ama as florestas e abomina a interação. Evitando qualquer avaliação de caráter racial ele atribui à forma institucional da colonização portuguesa no Brasil um incentivo poderoso a essa fragmentação. O que fica na análise dele, na verdade, é um aviso: se instituições públicas não forem produzidas o país, a natureza não vai cuidar, não vai resolver esse problema. Mais do que um diagnóstico há nisso certa maldição analítica para as nossas interpretações futuras do Brasil.

A fragmentação moderna é aquela que vamos conhecer a partir de 64. Werneck referiu-se a isso ontem, eu mesmo escrevi sobre isso em algum momento. A idéia é que o experimento de 64 é uma associação única na história das ditaduras recentes, entre modernização altamente acelerada 
- modernização no sentido de deslocamento completo em todas as organizações fundamentais da estrutura social brasileira - e destruição de qualquer malha de proteção institucional da sociedade; a sociabilidade é aniquilada. Nenhuma ditadura contemporânea apresenta essa associação no grau de radicalidade do Brasil, a começar por todas as ditaduras latinoamericanas. Nenhuma delas têm uma perspectiva de reconfiguração social como a que acabou sendo implantada com a ditadura brasileira. A Argentina talvez possa servir como exemplo contrário. A mesma coisa vale para os governos autoritários europeus. No caso brasileiro a sociedade é completamente refigurada, reconfigurada mesmo, e ao mesmo tempo são limitadíssimas as formas de expressão, de proteção institucional para o que se estava gerando.

Produzem-se atores sociais sem expressão política, esse é o ponto. A linguagem da política se desqualifica. Na verdade a vitória de 64 é a vitória de uma leitura economicista do mundo brasileiro, a idéia de que os atores valem o que valem, no âmbito produtivo, no âmbito da sociabilidade mais básica, na dimensão do trabalho, na dimensão da economia. Nesse sentido é um diagnóstico vitorioso e está em pleno curso no país. Na verdade o que se faz é dar curso a essa desqualificação, a essa erosão da política, aposta-se na natureza brasileira, na idéia de que a natureza brasileira vai para algum lugar, e a política se esvazia enquanto âmbito de correção, de intervenção, de compensação, de totalização dessa experiência.

A política é pensada com os instrumentos da análise institucional, que evidentemente são importantes para entender como funciona o Congresso, como são as eleições, como se vota. Claro que nenhuma agenda de ciência social decente pode excluir esses temas. A questão é: isso é tudo, isso é tudo o que nós podemos dizer em relação à política? Qual é o nexo desse Congresso com a sociedade brasileira? Acho que esse é o ponto. Sabemos bastante, nossos instrumentos de mensuração são sofisticados para entender o funcionamento interno desses objetos, mas sabemos muito pouco a respeito de como é que isso se conecta para baixo, que potências estão aparecendo. Suspeito de hiatos imensos. Isso apareceu na fala de Luiz Eduardo Soares, a idéia do desenvolvimento desigual, como se fossem dois mundos, e nós não temos instrumentos analíticos para tratar disso, talvez porque a nossa atenção não esteja muito focada nisso. $\mathrm{O}$ meu tema do dissídio com relação à Ciência Política de modo algum é uma defesa excludente de uma dimensão puramente utópica. É factual também, assinala temas que não são considerados mesmo na dimensão factual. Não se trata de transformar os cientistas 
políticos num bando de nefelibatas que ficam sonhando com mundos alternativos. Trata-se de dar expressão a problemas que a disciplina está perdendo a capacidade analítica para enfrentar.

Como se faz isso? Favorecendo uma reflexão, uma prática da disciplina que não seja totalmente colonizada pelo minimalismo, porque o minimalismo é invencível. O minimalismo é pilotado por uma definição de natureza humana invencível, porque essa definição de natureza humana que está presente na teoria é a mesma definição de natureza humana que está no mundo, porque as duas vêm da mesma matriz. A teoria da escolha racional é correta, ela descreve exatamente o modo pelo qual os seres humanos se comportam, porque o mundo foi configurado dessa maneira. Para perceber isso é fundamental ficar atento à grande tradição da teoria política, que não é uma tradição única, que acumula conhecimentos. É uma tradição de conflito insolúvel, que no entanto põe no mundo objetos, propostas, idéias, suposições, que decantam na vida e configuram os próprios objetos de que a ciência política empírica vai tratar. Do contrário teríamos que supor que partidos, parlamentos, judiciários e coisas do gênero brotam como cogumelos. Além do movimento social, além da história, além do interesse, evidentemente, isso é posto no mundo a partir de exercícios de invenção intelectual.

A minha preocupação não é com não tratarmos desses objetos, mas com tratarmos desses objetos desmemoriadamente. Porque, se o fizermos, abandonaremos a dimensão antecipatória da teoria política, e daqui a duas ou três gerações não haverá mais memória. Os fatos falarão por si, e nós temos razões de sobra para não aceitar que os fatos falem por si.

MARCO AURÉLIO NOGUEIRA - Primeiro, concordo com Werneck, temos que aprender a considerar o outro lado da Lua. Será que nós só temos porcaria nas ciências sociais? Muito pelo contrário. Junto com esses avanços tópicos, essa massa de coisas, vieram também grandes estudos, sem dúvida nenhuma avançamos nesse particular. Verdade que nesse mundo de ciências democratizadas ou no mundo democratizado das ciências temos também problemas. Então uma parte desse diálogo se resolve olhando um lado da Lua e outra parte se resolve olhando o outro.

$\mathrm{Na}$ sua intervenção Boaventura levantou dois pontos extremamente sugestivos e importantes. Um deles aflorou claramente na intervenção de Luiz Eduardo Soares, que é essa questão da convivência de esta- 
dos democráticos com sociedades fascistas, ou tendencialmente fascistas, ou fascistizantes. Por essa via é possível fazer uma ligação com o discurso de Luiz Eduardo, no sentido de perguntar como se pensa hoje a violência no Brasil. Essa proposta de Boaventura permite um avanço analítico, que ajudaria a dar conta de porque no senso comum a violência ou é reduzida imediatamente a um subproduto mecânico da pobreza, ou é vista como caso de polícia, perdendo-se a dimensão da política, a dimensão da cultura.

Outra questão importante é essa do projeto nacional, que seguramente é um problema não resolvido. Pensar o projeto nacional não apenas no ambiente nacional, mas fazendo as ligações do nacional com o regional, com o continental, com o mundial, já que as nações hoje vivem num mundo categoricamente transnacional, é instigante, é uma questão que deveria estar no centro da agenda das ciências sociais.

$* * *$

LUIZ EDUARDO SOARES - Começo pela observação de Tullo Vigevani. Estou convencido que não se trata de uma dualidade de valores, de modos de vida, de estilos de vida ou de culturas. Convivendo por um ano e meio, quase dois anos, com as favelas do Rio de Janeiro, com os favelados, as comunidades, eu estou convencido de que não há de modo algum a constituição de valores alternativos. Há uma sociabilidade alternativa, eventualmente imposta - depois vou comentar a intervenção de Boaventura - mas o horror é verdadeiro. É difícil entender como pode haver de fato esse terror e ao mesmo tempo o carnaval, o cinema, o futebol, as pessoas rindo pelas esquinas. A mãe, o pai, o irmão, não dormem, ficam pensando que o seu filho pode ser morto antes de chegar em casa, vivem em sobressalto permanente, sofrem muito com isso. A qualquer hora que se suba uma favela do Rio de Janeiro para discutir isso reúne-se quantas pessoas se quiser. Se $\mathrm{O}$ caso que contei, do líder comunitário que não pode abrir a janela, é eloqüente. Há sim terror, um sofrimento enorme. As pessoas acabam naturalizando, como tudo na vida. Naturaliza-se e se absorve, mas a um preço altíssimo, eu não sei quantas pessoas sucumbem à essa tensão, porque não se morre só de tiro, morre-se de várias maneiras e em vida também. E vou falar do outro lado da Lua exatamente me apropriando desse terror.

Há indignação, uma revolta surda, não há de modo algum essa duplicidade. Se houvesse multiplicidade de códigos, de valores etc., estaríamos numa situação pior, teríamos que pensar a ação de outra maneira, 
a política de outra maneira. Nesse sentido a nossa situação é melhor. De fato existe o terror e ele não é mediado por outros códigos, outros símbolos. Essa população vive o terror como terror, sabe que aquilo é ilegal e preferiria ter um Estado democrático de direito, e sabe o que isso significa. E aplaude quando a polícia atua de maneira correta, digna, honrada, respeitosa, adora a presença dessa polícia e se sente contemplada por essa presença, quando ela se dá nesses termos, e compreende a importância da legalidade democrática, das liberdades democráticas. Isso é compreendido, isso é vivido, de modo que nisso estamos muito próximos de contar com uma base de massa para a superação desse limite, de uma forma unitária e democrática.

Quanto à idéia dos enclaves fascistas, eu faria uma qualificação, não sei se Boaventura concordaria. Eu só aceitaria a hipótese se nós estivéssemos pensando em relações de poder, e não sei se estamos pensando em relações de poder. Ou seja, "fascista" - eu não gosto da qualificação, não me parece precisa, mas enfim, fascista, bárbaro, é o terror que é imposto por alguns armados sobre um conjunto conforme um código definido a $d$ hoc. Se for assim, então muito bem, nós temos isso. Mas não significa que essa sociedade seja fascista. Significa que esse micropoder é fascista. A sociedade se rebela, está indignada, procura resistir, e adoraria reverter esse quadro. Ela não está comprometida e não necessariamente absorve valores que endossem ou legitimem esse poder, esse poder é ilegítimo mesmo para essa comunidade. Vale lembrar aqui, como contraste com as observações de Tullo Vigevani, um trabalho antigo e matricial de Boaventura, de grande importância para nós no Brasil, o seu estudo sobre os códigos jurídicos populares. Os modos de compreensão do conflito, as linguagens mediadoras, tudo isso certamente se desenvolve em comunidades com suas especificidades, exigindo conversibilidades e o exercício das traduções interculturais. Essa é uma dimensão muito rica da diversidade, mas não chega a configurar uma pluralidade de valores políticos nos termos que eu entendi que Tullo dizia.

Vou retomar a questão de Marco Aurélio Nogueira a partir de um ângulo mais amplo, retomando a observação de Werneck. Não existe a política do pequeno número, não há política do e no pequeno número. Aí há condomínio de neuroses, de afetos e intersubjetividades que se compõem, isso não é política. Para haver, de fato, a possibilidade de pensar politicamente uma realidade é necessário o grande número, porque aí se cria uma outra lógica, uma outra dinâmica. Abrir a comunidade à ampla participação é condição prévia para qualquer intervenção política nesse sentido mais específico. Quanto à sua idéia pluralista de que há os 
problemas, as crises, mas por outro lado há avanços, e que esses engates institucionais da academia são importantes, essa visão pluralista pareceme corretíssima.

O outro lado da Lua, em relação ao que eu disse, é a dimensão de otimismo, otimismo que de alguma forma pode estar presente, embora as observações que eu fiz tenham sido muito sombrias. Sou otimista porque acho que apesar de todos aqueles problemas, hoje nós estamos num patamar diferente, porque houve um movimento muito interessante da sociedade brasileira. Há a consciência de o que foi feito até aqui não funcionou, que apostar na barbárie para conter a barbárie não funcionou, que dar liberdade à polícia e tratar o sistema de segurança como algum objeto de terceira categoria, negligenciável, não funcionou. Isso degradou essas instituições, inviabilizou a constituição de qualquer sistema minimamente democrático e civilizado, e criou esse quadro que temos. Esse quadro foi criado pela direita, pelos conservadores, por sua hegemonia. E há uma certa consciência de que essa também é uma área passível de tratamento racional. Isto pode parecer ingênuo e absurdo, mas empiricamente não é. De fato, as elites pareciam tão distantes desse mundo, que viam com certo pudor e repugnância, que nunca imaginaram que se pudesse, de fato, desenvolver políticas específicas de transformação, de reforma e de reorganização estrutural. Quando experiências internacionais mostram que isso é possível, quando se começa a exercitar uma outra linguagem no Brasil, parece que horizontes se abrem, apontando para um grande consenso em torno da idéia de que o respeito aos direitos humanos é crucial para a eficiência policial, assim como a eficiência policial o é para a própria efetividade dos direitos humanos. É muito importante o modo como as instituições estão se situando, se requalificando para discutir o problema, não só a academia, mas o Ministério Público está discutindo internamente novas possibilidades de contribuição. Setores e segmentos importantes das instituições policiais começam a se repensar, há uma intelectualidade desse mundo que estava reprimida e marginalizada, ela própria sem referências externas e sem autoconfiança, que começa a elaborar um discurso, e também na esquerda vemos emergir espaço para uma consideração diferente dessa problemática. Penso, enfim, que estamos transitando por um outro nível de articulação, de debate, de reconhecimento dos problemas.

$* * *$

GILDO MARÇAL BRANDÃO - A temática das dificuldades de pensar e de por que pensar foi aqui reconhecida em dois níveis: um diz 
respeito às dificuldades no processo global da sociedade, e a outra é interna à atividade científica. As observações dessa mesa se concentraram, pelo menos nas duas primeiras intervenções, na questão das dificuldades internas à atividade científica. Embora reconhecendo que Werneck tem razão quando aponta a democratização, que é um avanço na própria ciência social, lembro que democratização também traz barbárie. Todo documento de civilização também é documento de barbárie, como dizia Walter Benjamin. E nas ciências sociais temos a barbárie que Renato Lessa apontou, da adoração do método, da metodolatria. Hoje estamos sob o império das agendas de pesquisa que infletem numa dada direção. Essa metodolatria é que nos fecha primeiro no institucional, na compartimentação. Segundo, nos impede de pensar as dificuldades para além das ciências sociais. Disso resulta algo grave: a dificuldade de pensar a natureza do capitalismo contemporâneo. Nossa compartimentação científica nos impede de pensar isso. Pensar a natureza do capitalismo contemporâneo significa também que não se pode pensar a nação nos limites da nação. $E$ não estamos fazendo isso, estamos engolfados numa internacionalização passiva da ciência social. Não há saída, temos que enfrentar o lado de barbárie da nossa democratização.

OCTÁVIO IANNI - Tivemos a sorte de ter um debate bastante vivo. As posições apresentadas aqui ajudaram a ampliar as colocações feitas ontem. Estamos pouco a pouco a caminho de recriar ou reinventar o Brasil. Ao mesmo tempo vamos nos posicionar, como intelectuais mas também como cidadãos, numa sociedade que provavelmente poderá reencontrar o seu projeto numa perspectiva nova, entre o globalismo e o regionalismo. 